achieving results on the ground? Wider practice would follow, though inevitably slowly.

Januse Rygielsky, President of their Committee of Nature Protection, described the problem of Polish National Parks. All have wilderness areas within their boundaries, but in five of the 13 Parks you can also see the effect of Man's activity.

Within the theme of Meeting the Public, Crispin Gill talked on planning and the press. This often amounted to the difference between what the planner thought was important and what the journalist thought the public would be interested in; the two needed bringing together. Colonel Eric Bardell described the most direct contact of all-the work of a Ranger Service.

Madame Laurence Paley talked about the French Ecomusé, with particular reference to the Parc Naturel d'Amorique. Deputising for her husband, the Director of that Park, she also talked on the subject of 'Farmers and the Public'. The French were working now with the local population to bring new life to old cultures - not by imposing an outside solution or a mere museum or urbantype preservation, but by encouraging a renewal of traditional agriculture instead of neglect. With the aid of some money, very little power, but a lot of patience, the idea was to bring back pride, life, and production - and, in the process, protect the scenery because the local population wanted to do so.

In 1979 there is to be a conference in the Bavarian Forest National Park, and in the Spring of 1980 there will again be a meeting at Losehill Hall, when the subject will be Land Management and Conservation.

Theodore S. Burrell,

National Park Officer

Peak District National Park

Aldern House

Baslow Road

Bakewell

Derbyshire, DE4 IAE, England.

Note: A full report of the Conference is available at $11.80 \mathrm{p}$ (including overseas postage) from the National Park Office, Peak District National Park, Aldern House, Bakewell, Derbyshire, $\mathrm{DE} 41 \mathrm{AE}$, England. Details of future such conferences will be sent on request as soon as they become available.

IUCN'S FOURTEENTH GENERAL ASSEMBLY, HELD IN ASHKHABAD, USSR, 26 SEPTEMBER-5 OCTOBER 1978

'Unusually productive and harmonious', was how one old IUCN hand summed up the 14th Session of the General Assembly, as more than 300 delegates and observers left Ashkhabad (Turkmenian SSR) for home or field trips.

IUCN's General Assembly meets every three years, and from 26 September to 5 October 1978 the delegates of 191 members from 50 countries got to grips with the World Conservation Strategy, the IUCN Triennial Programme, and a host of other issues - and elected Professor Mohamed Kassas of Egypt to the presidency (following the decision of Professor Donald Kuenen not to stand for reelection), and managed to celebrate IUCN's 30th birthday as well.

By a strange coincidence, October 1978 also constituted a 30th anniversary for the Assembly's host city. In the very month that IUCN was founded, Ashkhabad was flattened by a disastrous earthquake. Since then the city has made an impressive recovery, and today Ashkhabad is a remarkably green and tree-lined oasis in the desert a tribute to the engineering feat of the Karakum Canal.

\section{World Conservation Strategy}

The participants brought with them to the Assembly an evident desire to consolidate the changes of the recent past and to set IUCN and the world conservation movement on a course for greater achievements. 'From now on there is going to be a World Conservation Strategy, even if it has to be improved and adapted as we go along', said Max Nicholson, one of conservation's 'senior statesmen'. 'We have moved from the tactical defensive, dealing with bits and pieces of wild Nature, to a posture of strategic initiative over the entire biosphere.'

The Strategy will go to a third draft before being published in 1979. While delegates wanted to delete very little, they had many things to add. Several made strong pleas for more on human population, conservation education, and implementation.

The consensus seemed to be that the second draft was on the right lines and, with certain changes and additions, was fit to be published. Chief among the improvements called for were:

-A fuller, more focused discussion of the relationship between conservation and socio-economic factors-particularly human population increase.

- A more thorough account of the development process and how the World Conservation Strategy should influence it.

- More on conservation education, and also on planning and legislation.

- Sections on pollution, toxic chemicals, and soil and water conservation.

- Much more on implementation of the Strategy - on how the recommended action can be achieved rather than what action is necessary -with more explicit and precise recommendations to governments and those organizations that should implement the Strategy.

The Ashkhabad version of the Strategy will be operative in its initial form for a few years only. The General Assembly decided that it should be revised and updated every three years, and reviewed at each ordinary session of the Assembly.

\section{High Priority for Commissions}

Strong pleas came for more support for the IUCN Commissions.* Members of the Commissions repeatedly stressed the need for at least a minimum level of assured financing if they are to make an effective contribution to the Programme. The General Assembly supported this view. In its resolution on the Programme, the Assembly approved the draft programme and estimates prepared by the Secretariat. It also gave the Director-General the flexibility of action he requested - subject to certain guidelines, in particular on the Commissions and the regional desks.

*IUCN's six Commissions comprise the Commission on National Parks and Protected Areas, the Commission on Ecology, the Commission on Environmental Policy, Law, and Administration, the Survival Service Commission, the Commission on Education, and the Commission on Environmental Planning. 
The main guidelines are:

- Financing of Commissions shall have a high priority, and all Commissions shall have support for 'executive capacity and operating expenses'.

- The functions of regional desks of IUCN shall be to provide links with members in the regions (especially those in 'developing countries'), ensure that regional considerations are reflected in IUCN activities, and help catalyse the implementation of the World Conservation Strategy.

- Greater support should be given to conservation education, information, and public awareness.

-A priority shall be given to maintenance of the IUCN Red Data Book at the highest attainable level of reliability.

-IUCN should take whatever steps are necessary to examine, analyse, and if appropriate implement, a development programme to ensure that development activities take conservation into account.

\section{Conservation for Development}

With regard to this last point, the General Assembly welcomed a proposal by Maurice F. Strong, Chairman of the IUCN Bureau, for a 'Conservation for Development' programme. The programme is intended to enable IUCN to respond to requests from developing countries for assistance with conservation-related development activities. The programme would draw on the financial resources of development-assistance agencies.

The Conservation for Development programme, like the development theme of the World Conservation Strat egy, is a response to mounting concern by governments of developing countries that too much of the development which they are buying today is wrecking their chances of sustainable, reasonably self-sufficient development tomorrow.

\section{Charter of Nature}

IUCN's General Assembly in Zaire (1975), in response to a call by President Mobutu, had agreed that a Charter of Nature should be drawn up, the document to be signed by governments as signalling their intention to abide by broad conservation principles. In Ashkhabad the Charter was presented in draft form and its merits and demerits were hotly debated. The draft is to be rewritten and will be available for review by all IUCN members requesting a copy.

In a notable address to the General Assembly, H. E. Luis Echeverria Alvarez - former President of Mexico and now Mexican Ambassador to UNESCO - called for 'a new social and economic order, which will manage Nature's resources fairly and logically while aiming for a high and equitable quality of life'. This is the first time a major Third World figure has explicitly linked the New International Economic Order with conservation of Nature and natural resources.

Patrick Allen

IUCN Secretariat

1110 Morges

Switzerland.
UNDP/UNEP MEETING OF GOVERNMENT EXPERTS FOR DEVELOPING A COOPERATIVE PROGRAMME ON THE PRACTICAL APPLICATIONS OF RENEWABLE SOURCES OF ENERGY IN THE MEDITERRANEAN REGION, HELD IN MALTA, 9-13 OCTOBER 1978

Fifteen Mediterranean countries and the European Economic Community have agreed on a regional co- $x$ operative plan for the practical use of renewable sources of energy in the Mediterranean. This means that an effort will be made to harness the sun and the wind, and to use biomass consisting of plant and animal matter, on a larger and more efficient scale than hitherto.

The agreement was reached at a recent five-days' meeting, in Malta, of government experts from Cyprus, Egypt, France, Greece, Israel, Italy, Libya, Malta, Monaco, Morocco, Spain, Syria, Tunisia, Turkey, Yugoslavia, and representatives from the EEC. Two countries made specific proposals: Malta and Turkey offered to act as hosts of regional Mediterranean centres for renewable sources of energy. It was agreed at the meeting that the centre in Malta would deal with technical assistance and training and exchange of information in the region, while an existing national institution in Turkey would be designated as a regional centre for solar energy research and development. These recommendations must be approved, however, at a major intergovernmental conference of the Mediterranean coastal states.

The experts at the Malta meeting, which was cosponsored and co-chaired by the United Nations Development Programme and the United Nations Environment Programme, devoted most attention to the use of solar energy for such purposes as household water- and spaceheating, pumping and desalination of water for drinking and irrigation, drying and preserving of food, and greenhouse cultivation. Interest was also expressed in harnessing wind-power for generating electricity and pumping water, and in the production of biogas from organic wastes for cooking and localized electricity supplies.

Whereas large-scale substitution of conventional energy by renewable sources will be difficult, the experts felt that renewable energy technologies for reducing dependence on conventional energy and improving the quality of rural life are available now. Moreover, substantial work in this field is already being done in the Mediterranean region. 'While this is especially important for the developing countries in the Mediterranean', said Stig Andersen, UNDP Assistant Administrator, 'vigorous promotion of such use of renewable energy would clearly bring economic benefits to the more industrialized countries as well'. 'We now have a framework for exploiting the considerable expertise on renewable energy that exists on both sides of the Mediterranean,' declared Peter S. Thacher, UNEP's Deputy Executive Director.

The discussion highlighted the need for assisting developing countries to establish their energy balance-sheets and to integrate the use of renewable sources of energy in their energy development strategies. It was generally agreed that the potential uses of renewable sources of energy were intimately linked to the social and economic development of the Mediterranean developing countries, most of which are located in arid and semi-arid zones. Two such uses were stressed: water desalination and distillation, and water pumping.

Mr Andersen further expressed UNDP's willingness to supplement the financing of concrete projects that 